\title{
The utilization of the energy of two mixtures of steam-volatile fatty acids by fattening sheep
}

\author{
By D. G. ARMSTRONG, K. L. BLAXTER, N. McC. GRAHAM \\ AND F. W. WAINMAN \\ Hannah Dairy Research Institute, Kirkhill, Ayr \\ (Received I 5 August 1957)
}

The energy of mixtures of steam-volatile fatty acids representative of those arising in the rumen when food undergoes microbial fermentation was utilized with high efficiency when given to fasting sheep, and was unaffected by the molar composition of the mixtures employed (Armstrong, Blaxter \& Graham, 1957). Given as the sole source of energy, however, acetic acid was poorly utilized (Armstrong \& Blaxter, I957a). It was shown later that when the acids were added singly to rations which themselves permitted a retention of energy, the individual acids were utilized for lipogenesis with much lower efficiencies than in the fasting animal and marked differences in the utilization of the individual acids were found (Armstrong \& Blaxter, $1957 b$ ). It was therefore important to establish whether different mixtures of the steam-volatile acids are utilized with constant efficiency when they are given to fattening animals.

The experiments described below were designed for this purpose.

\section{EXPERIMENTAL}

Sheep. Four adult castrated male sheep were used. Each had a permanent fistula into the dorsal sac of the rumen. The fistula was closed with a Perspex cannula.

Food and acid mixtures. Throughout the experiments the sheep were given $900 \mathrm{~g}$ daily of dried-grass pellets in two meals. The composition of the grass pellets is given in Table I. Each sheep was given in addition through the fistula 61 . of a dilute salt solution containing one of the following four steam-volatile fatty-acid mixtures:

(1) A mixture of acetic, propionic and $n$-butyric acids in the molar proportions 75 : I 5 : 10 to supply approximately $45^{\circ} \mathrm{Cal}$. daily.

Table r. Chemical composition of the dried-grass cubes given to the sheep

\begin{tabular}{lr}
\multicolumn{1}{c}{ Component } & $\begin{array}{c}\text { Dry matter } \\
(\%)\end{array}$ \\
Ash & $12 \cdot 4$ \\
Ether extract & $3 \cdot 8$ \\
Crude fibre & $25 \cdot 7$ \\
Crude protein & $17 \cdot 9$ \\
Nitrogen-free extractives & $40 \cdot 2$ \\
Cellulose & $26 \cdot 5$ \\
Non-cellulosic furfural & $6 \cdot 9$ \\
Lignin & $5 \cdot 2$
\end{tabular}


(2) The same mixture as ( $\mathrm{I})$, the concentration being doubled to provide approximately 900 Cal. daily.

(3) A mixture of acetic, propionic and $n$-butyric acids in the molar proportions $25: 45: 30$ to supply approximately $45 \circ \mathrm{Cal}$. daily.

(4) The same mixture as (3), the concentration being doubled to provide approximately 900 Cal. daily.

These four mixtures are subsequently referred to as the 'high acetic-acid mixture' ( $\mathrm{I}$ and 2 ) and the 'low acetic-acid mixture' ( 3 and 4 ) with the designation that they supplied either 450 or $900 \mathrm{Cal}$./day. The salt solution was that described by Armstrong \& Blaxter (1957a), and the periods in which it was given are referred to as control periods.

Each of the seven experimental periods lasted 7 days and was followed by an interval of at least 7 days when no fluid was infused into the rumen. In the 1 st, $4^{\text {th }}$ and 7 th experimental periods each sheep was given the control solution, and in the 2nd, $3^{\text {rd, }}$ $5^{\text {th }}$ and 6th periods each sheep was given the acid mixtures. The sequence in which the acid mixtures were given varied from sheep to sheep, according to a Latin-square design. The fluids were infused into the rumen at constant rates by means of slowspeed pumps (Armstrong \& Blaxter, I957 a). It will be noted that the control periods were systematically and not randomly arranged as were the periods in which acid infusions were given. If there had been large time trends in the measurements made, valid estimates of the experimental errors could not have been obtained. There were, however, no statistically significant differences between the mean values obtained during the three control periods, for any of the measurements studied, the only one approaching significance being that for urinary ketones $(0.05<P<0.10)$.

Samples taken. Faeces were collected quantitatively during the final 5 days of each 7 -day period. Urine was collected and measurements of the gaseous exchange were made during the last 4 days of the periods. Samples of rumen liquor and of venous (jugular) blood were taken at the end of the last day of each period.

Analytical methods. These were the same as those previously used (Armstrong \& Blaxter, 1957a). In addition the concentrations of the individual acids in the samples of rumen liquor were determined by the method of James \& Martin (1952), the preparation of the samples for this purpose being that described by Armstrong et al. (1957).

\section{RESULTS}

Conditions within the rumen. Table 2 summarizes the analyses of rumen liquor relating to the concentration of total steam-volatile fatty acids and to $\mathrm{pH}$. The addition of both mixtures of acids caused a fall in $\mathrm{pH}$ and a rise in the concentration of steam-volatile fatty acids. The changes, however, were small, and if the rumenliquor volume is taken to be $5^{-6} 1$., the accumulation of acid represented only a small fraction of the amounts given each day. This high efficiency of absorption serves to emphasize the difficulty of attempts to assess the quantities of acid produced in the rumen from the quantities which happen to be present at any one particular time. 
Table 3 shows the proportions of the individual acids making up the total steamvolatile fatty acids present in each of the samples of rumen liquor. No significant change took place in the composition of the steam-volatile fatty-acid mixtures of rumen liquor when the high acetic-acid mixture was given. This finding is not surprising because the composition of the mixture infused was very close to that of the mixture present in the rumen when no acids were given. When, however, the low acetic-acid mixture was given there were statistically significant changes. The proportion of propionic and $n$-butyric acids increased while the proportion of acetic acid

Table 2. Mean values with their standard errors for concentration of steam-volatile fatty acids in the rumen liquor, and the $p H$ of the rumen liquor of four sheep given two different mixtures of steam-volatile fatty acids

\begin{tabular}{|c|c|c|c|c|c|}
\hline \multirow[b]{2}{*}{ Treatment } & \multirow{2}{*}{$\begin{array}{l}\text { Approximate } \\
\text { calories } \\
\text { supplied } \\
(\mathrm{Ca} 1 . / 24 \mathrm{~h})\end{array}$} & \multicolumn{2}{|c|}{$\mathrm{pH}$ of rumen liquor } & \multicolumn{2}{|c|}{$\begin{array}{l}\text { Steam-volatile fatty } \\
\text { acids in rumen liquor } \\
\text { (m-equiv./100 ml.) }\end{array}$} \\
\hline & & Mean & Change & Mean & Change \\
\hline Control & None & $5 \cdot 86 \pm 0.03$ & - & $6 \cdot 47 \pm 0.22$ & 一 \\
\hline High acetic-acid mixture & $\begin{array}{l}450 \\
900\end{array}$ & $\begin{array}{l}5.64 \pm 0.05 \\
5.53 \pm 0.05\end{array}$ & $\begin{array}{l}-0.22 \\
-0.33\end{array}$ & $\begin{array}{l}7 \cdot 18 \pm 0 \cdot 3^{8} \\
8 \cdot 87 \pm 0 \cdot 3^{8}\end{array}$ & $\begin{array}{l}+0.71 \\
+2.40\end{array}$ \\
\hline Low acetic-acid mixture & $\begin{array}{l}450 \\
900\end{array}$ & $\begin{array}{l}5.68 \pm 0.05 \\
5.67 \pm 0.05\end{array}$ & $\begin{array}{l}-0.18 \\
-0.19\end{array}$ & $\begin{array}{l}7.62 \pm 0.3^{8} \\
8 \cdot 17 \pm 0.3^{8}\end{array}$ & $\begin{array}{l}+I \cdot 15 \\
+I \cdot 70\end{array}$ \\
\hline Standard error of mean differences & 一 & - & \pm 0.06 & - & \pm 0.44 \\
\hline
\end{tabular}

Table 3. Mean values with their standard errors for percentage composition of the steam-volatile fatty-acid mixtures present in the rumens of four sheep given two different mixtures of steam-volatile fatty acids

\begin{tabular}{|c|c|c|c|c|}
\hline \multirow[b]{2}{*}{ Treatment } & \multirow{2}{*}{$\begin{array}{l}\text { Approximate } \\
\text { calories } \\
\text { supplied } \\
(\text { Cal. } / 24 \text { h) }\end{array}$} & \multicolumn{3}{|c|}{$\begin{array}{c}\text { Composition of steam-volatile } \\
\text { fatty-acid mixture } \\
\text { (m-equiv./100 m-equiv. total acid) }\end{array}$} \\
\hline & & Acetic & Propionic & $n$-Butyric \\
\hline Control & None & $67 \cdot 9 \pm x \cdot 8$ & $19 \cdot 5 \pm 1 \cdot 4$ & $12.6 \pm 0.8$ \\
\hline High acetic-acid mixture & $\begin{array}{l}450 \\
900\end{array}$ & $\begin{array}{l}68 \cdot 3 \pm I \cdot I \\
66 \cdot 5 \pm I \cdot I\end{array}$ & $\begin{array}{l}19.5 \pm 0.8 \\
21.4 \pm 0.8\end{array}$ & $\begin{array}{l}12 \cdot 2 \pm 0.5 \\
12.4 \pm 0.5\end{array}$ \\
\hline Low acetic-acid mixture & $\begin{array}{l}45^{\circ} \\
900\end{array}$ & $\begin{array}{l}5^{8 \cdot 1} \pm \mathrm{I} \cdot \mathrm{I} \\
49^{\circ} 7 \pm \mathrm{I} \cdot \mathrm{I}\end{array}$ & $\begin{array}{l}26.5 \pm 0.8 \\
32.9 \pm 0.8\end{array}$ & $\begin{array}{l}15.4 \pm 0.5 \\
17.5 \pm 0.5\end{array}$ \\
\hline
\end{tabular}

decreased. The mixture given contained a predominance of propionic and butyric acids. The concentrations noted represent steady-state relationships between the production of acids from the basal ration, the constant inflow of the mixture of acids given through the fistula and the absorption of the acids from the rumen wall. The composition of rumen liquor with respect to the individual acids contained therein was similar in both instances to the composition of the liquor recorded in ruminants on natural foods as previously summarized (Armstrong et al. 1957).

Absorption of the energy-yielding constituents of the basal ration. The mean faecal excretion of energy by the sheep expressed as the heat of combustion of the faeces is given in Table 4 . When the sheep were given daily $900 \mathrm{Cal}$. of the high acetic-acid 
mixture the loss of energy in the faeces increased considerably. As shown in Table 4, this increase was associated with a reduction in methane production to about half of that during the control period. Since the fermentation and digestion of the basal diet was altered, the heat increment of the high acetic-acid mixture given to supply 900 Cal. cannot be calculated.

It has already been noted that the concentration of steam-volatile fatty acids in the rumen increased from 6.47 to $8.87 \mathrm{~m}$-equiv./100 $\mathrm{ml}$. when the high acetic-acid mixture was given. The latter concentration cannot be regarded as large, indeed much higher concentrations have been observed in sheep given natural foods. Nor is a $\mathrm{pH}$ of 5.52 to be regarded as indicative of serious abnormality. The present observation serves to emphasize how delicately balanced are the microbial populations of the rumen, and what relatively small changes in conditions can modify their activity. It seems probable that the high concentration of acetic acid per se in rumen fluid was the most likely cause of the derangement in the fermentation process.

Table 4. Mean values with their standard errors for heats of combustion of the faeces and of the methane produced by four sheep given mixtures of the steam-volatile fatty acids, and the mean apparent absorption of energy-yielding constituents

\begin{tabular}{|c|c|c|c|c|c|}
\hline \multirow[b]{2}{*}{ Treatment } & \multirow[b]{2}{*}{$\begin{array}{l}\text { Approximate } \\
\text { calories } \\
\text { supplied } \\
(\text { Cal. } / 24 \mathrm{~h})\end{array}$} & \multirow[b]{2}{*}{$\begin{array}{c}\text { Faecal } \\
\text { energy } \\
(\text { Cal. } / 24 \mathrm{~h})\end{array}$} & \multirow[b]{2}{*}{$\begin{array}{c}\text { Methane } \\
\text { energy } \\
\text { (Cal./24 h) }\end{array}$} & \multicolumn{2}{|c|}{$\begin{array}{l}\text { Apparent absorption } \\
\text { of energy-yielding } \\
\text { constituents } \\
\text { (Cal./24 h) }\end{array}$} \\
\hline & & & & $\begin{array}{l}\text { From } \\
\text { basal } \\
\text { ration }\end{array}$ & $\begin{array}{l}\text { Acid } \\
\text { actually } \\
\text { supplied }\end{array}$ \\
\hline Control & None & I I $73 \pm 45$ & $269 \pm 7$ & 2304 & None \\
\hline High acetic-acid mixture & $\begin{array}{l}45^{\circ} \\
900\end{array}$ & $\begin{array}{l}1170 \pm 77 \\
1415 \pm 77\end{array}$ & $\begin{array}{l}217 \pm 12 \\
136 \pm 12\end{array}$ & $\begin{array}{l}2307 \\
2072\end{array}$ & $\begin{array}{l}441 \\
874\end{array}$ \\
\hline Low acetic-acid mixture & $\begin{array}{l}45^{\circ} \\
900\end{array}$ & $\begin{array}{l}1171 \pm 77 \\
1207 \pm 77\end{array}$ & $\begin{array}{l}242 \pm 12 \\
208 \pm 12\end{array}$ & $\begin{array}{l}2306 \\
2270\end{array}$ & $\begin{array}{l}435 \\
883\end{array}$ \\
\hline
\end{tabular}

The low acetic-acid mixture given to supply $900 \mathrm{Cal}$. also resulted in a significant fall in $\mathrm{CH}_{4}$ production, and presumably there were associated changes in the fermentation of the carbohydrate of the basal ration. The increase in the faecal loss of energy, though not statistically significant, suggests that it might have resulted from a reduction in the activity of cellulose-fermenting organisms. The magnitude of the effects was, however, small, and they have been ignored in subsequent analysis of the results.

With the low acetic-acid mixture and the high acetic-acid mixture given to supply $45^{\circ}$ Cal. there was no significant change in faecal excretion or methane production.

Composition of the blood. The content of sugar, ketones and steam-volatile fatty acids in the whole blood, and the $\mathrm{CO}_{2}$-combining capacity of the blood plasma are summarized in Table 5 .

There was no significant change in the $\mathrm{CO}_{2}$-combining capacity of the plasma when the acids were given, although there were small increases in the quantities of steamvolatile fatty acids in peripheral blood when the high acetic-acid mixture was given. Presumably these additional quantities were completely buffered without significant 
change in the bicarbonate buffers of the plasma. In any event, they were so small that it is doubtful if, even if not buffered by a system other than bicarbonate, they could be detected by a change in the $\mathrm{CO}_{2}$-combining capacity of the plasma.

The sugar content of the blood was slightly depressed by all four treatments, but the depression was statistically significant only when the high acetic-acid mixture was given to supply $900 \mathrm{Cal}$. All values can be regarded as within the normal range of concentration to be expected in sheep receiving normal rations. There was a depression of the ketone content of the blood when the acids were given, but the changes were all small, and in no instance were they statistically significant.

Table 5. Mean values with their standard errors for concentration of sugar, ketones and steam-volatile fatty acids in whole blood and the $\mathrm{CO}_{2}$-combining capacity of the plasma of four sheep given two different mixtures of steam-volatile fatty acids

\begin{tabular}{|c|c|c|c|c|c|}
\hline Treatment & $\begin{array}{l}\text { Approximate } \\
\text { calories } \\
\text { supplied } \\
\text { (Cal. } / 24 \mathrm{~h} \text { ) }\end{array}$ & $\begin{array}{c}\mathrm{CO}_{2} \text {-combining } \\
\text { capacity of } \\
\text { plasma } \\
\text { (vol./roo ml.) }\end{array}$ & $\begin{array}{l}\text { Steam-volatile } \\
\text { fatty acids of } \\
\text { whole blood } \\
\text { (m-equiv./ } \\
\text { I00 ml.) }\end{array}$ & $\begin{array}{c}\text { Sugar of } \\
\text { whole blood } \\
(\mathrm{mg} / 100 \mathrm{ml} .)\end{array}$ & $\begin{array}{c}\text { Ketones of } \\
\text { whole blood } \\
\text { (mg acetone/ } \\
\text { roo ml.) }\end{array}$ \\
\hline Control & None & $50 \cdot 0 \pm I \cdot 2$ & $0.048 \pm 0.004$ & $48 \cdot 7 \pm I \cdot O$ & $7 \cdot 86 \pm 2 \cdot 22$ \\
\hline $\begin{array}{l}\text { High acetic- } \\
\text { acid mixture }\end{array}$ & $\begin{array}{l}45 \circ \\
900\end{array}$ & $\begin{array}{l}49.4 \pm 2 \cdot 0 \\
50 \cdot 6 \pm 2 \cdot 0\end{array}$ & $\begin{array}{l}0.089 \pm 0.008 \\
0.066 \pm 0.008\end{array}$ & $\begin{array}{l}45 \cdot 5 \pm I \cdot 8 \\
44 \cdot 3 \pm I \cdot 8\end{array}$ & $\begin{array}{l}4 \cdot 12 \pm I \cdot 28 \\
4 \cdot 16 \pm I \cdot 28\end{array}$ \\
\hline $\begin{array}{l}\text { Low acetic- } \\
\text { acid mixture }\end{array}$ & $\begin{array}{l}45^{\circ} \\
900\end{array}$ & $\begin{array}{l}52 \cdot 1 \pm 2 \cdot 0 \\
47 \cdot 3 \pm 2 \cdot 0\end{array}$ & $\begin{array}{l}0.052 \pm 0.008 \\
0.036 \pm 0.008\end{array}$ & $\begin{array}{l}46 \cdot 2 \pm I \cdot 8 \\
48 \cdot I \pm I \cdot 8\end{array}$ & $\begin{array}{l}7 \cdot 65 \pm I \cdot 28 \\
6 \cdot 60 \pm I \cdot 28\end{array}$ \\
\hline
\end{tabular}

The analyses of the blood suggest, therefore, that no abnormal metabolic state was induced in the tissues of the animal by the continued administration of the acids.

Composition of the urine. Table 6 summarizes the determinations of the amounts of ketones and steam-volatile fatty acids excreted in the urine. There was no significant change in excretion of steam-volatile fatty acids when the two mixtures were given. The errors attached to the urinary excretion of ketones were high, largely as a result of considerable variation in the excretion by two of the sheep. The differences to be seen in the table suggest, however, that the low acetic-acid mixture at both levels of intake and the high acetic-acid mixture given to supply $900 \mathrm{Cal} .24 \mathrm{~h}$ reduced the urinary excretion of ketones. The amounts of ketones excreted were, however, relatively small throughout.

Table 6. Mean values with their standard errors for excretion in the urine of steam-volatile fatty acids and of ketones by four sheep when given two mixtures of steam-volatile fatty acids

\begin{tabular}{|c|c|c|c|}
\hline Treatment & $\begin{array}{l}\text { Approximate } \\
\text { calories } \\
\text { supplied } \\
\text { (Cal./24 h) }\end{array}$ & $\begin{array}{c}\text { Steam-volatile } \\
\text { fatty acids } \\
\text { (equiv. } / 24 \mathrm{~h} \text { ) }\end{array}$ & $\begin{array}{c}\text { Ketones } \\
\text { (g acetone } / 24 \mathrm{~h} \text { ) }\end{array}$ \\
\hline Control & None & $0.16 \pm 0.01$ & $0.95 \pm 0.19$ \\
\hline High acetic-acid mixture & $\begin{array}{l}45^{\circ} \\
900\end{array}$ & $\begin{array}{l}0.15 \pm 0.02 \\
0.15 \pm 0.02\end{array}$ & $\begin{array}{l}0.85 \pm 0.33 \\
0.25 \pm 0.33\end{array}$ \\
\hline Low acetic-acid mixture & $\begin{array}{l}45^{\circ} \\
900\end{array}$ & $\begin{array}{l}0.15 \pm 0.02 \\
0.17 \pm 0.02\end{array}$ & $\begin{array}{l}0.13 \pm 0.33 \\
0.24 \pm 0.33\end{array}$ \\
\hline
\end{tabular}


Effect on heat production. The mean energy retention of the sheep during the control periods was $100 \mathrm{Cal} .24 \mathrm{~h}$, which represents a plane of nutrition of approximately $0 \cdot \mathrm{I}$ (Blaxter \& Graham, I955), that is close to the maintenance datum. When the acids were given, the net result of their metabolism must therefore have been synthesis of fat and protein.

Heat production was calculated from the metabolic results in two ways, firstly from the non-protein respiratory quotient, the $\mathrm{CH}_{4}$ production and the oxygen consumption (the R.Q. method), and secondly from the energy intake less the sum of energy in faeces, urine, methane, and in protein and fat stored in the body, the protein and fat storage being determined from the retentions of $\mathrm{C}$ and $\mathrm{N}$. The second method is called the ' $\mathrm{C}$ - and $\mathrm{N}$-retention method'. The logical assumptions involved in using the former method and the relatively high error involved in the latter method have already been commented on (Armstrong \& Blaxter, 1957 b).

In Table 7 the mean estimates of heat production obtained by the two methods are given together with the standard deviation of a single difference. The table shows that there was no systematic difference between the determinations made by the two methods, but the standard deviation was, in general, slightly higher than the value of $\pm 56.6 \mathrm{Cal} . / 24 \mathrm{~h}$ obtained in previous experiments with intact sheep by identical analytical techniques and experimental methods (Blaxter \& Graham, 1956). The absence of systematic error makes the pooling of the results obtained by the two methods legitimate.

Table 7. Heat production determined by the respiratory-quotient method and by the $C$ - and $N$-retention method, and the standard deviation of differences. Results from twenty-six experiments with four sheep

\begin{tabular}{|c|c|c|c|c|c|}
\hline \multirow[b]{2}{*}{ Treatment } & \multirow[b]{2}{*}{$\begin{array}{c}\text { No. of } \\
\text { observations }\end{array}$} & \multicolumn{2}{|c|}{$\begin{array}{l}\text { Mean heat production } \\
(\text { Cal. } / 24 \mathrm{~h})\end{array}$} & \multirow{2}{*}{$\begin{array}{l}\text { Mean } \\
\text { difference } \\
\text { between the } \\
\text { two methods } \\
\text { (Cal./24 h) }\end{array}$} & \multirow{2}{*}{$\begin{array}{l}\text { Standard } \\
\text { deviation } \\
\text { of an } \\
\text { individual } \\
\text { difference }\end{array}$} \\
\hline & & $\begin{array}{l}\text { R.Q. } \\
\text { method }\end{array}$ & $\begin{array}{l}\mathrm{C}-\text { and N- } \\
\text { retention } \\
\text { method }\end{array}$ & & \\
\hline Control & I I* & $1753 \cdot 5$ & $1745^{\circ} 3$ & $+8 \cdot 2$ & $\pm 80 \cdot 8$ \\
\hline High acetic-acid mixture & 8 & 2050.0 & $2049 \cdot 3$ & +0.7 & $\pm 6 r \cdot I$ \\
\hline Low acetic-acid mixture & $7 \dagger$ & 1990.5 & $200 I \cdot 5$ & $-I 1 \cdot 0$ & $\pm 52 \cdot 6$ \\
\hline All treatments & 26 & $1908 \cdot 5$ & 1907.8 & $+0.7 \mathrm{I}$ & $\pm 68 \cdot 2$ \\
\hline
\end{tabular}

* One of the observations on the $\mathrm{C}$ and $\mathrm{N}$ retention was missing.

+ With sheep $T$ given $900 \mathrm{Cal}$. of this mixture, the determination of $\mathrm{C}$ and $\mathrm{N}$ retention was clearly in error by $160 \mathrm{Cal}$. and the pair of observations concerned was discarded.

Table 8 gives the results from which the heat increments were calculated. Each control value is the mean of three values, except that two control experiments only were used to compute the mean for sheep $T$. The calorie intakes as steam-volatile acids varied slightly from experiment to experiment owing to variable output of the pumps employed.

The results were analysed statistically and showed the mean heat increment of the high acetic-acid mixture to be $68 \cdot 2 \pm \mathrm{I} \cdot 8 \mathrm{Cal} . / \mathrm{r} 00 \mathrm{Cal}$. acid given and the mean heat increment of the low acetic-acid mixture to be $4 \mathrm{I} \cdot 9 \pm \mathrm{I} \cdot 2 \mathrm{Cal} / \mathrm{ro0} \mathrm{Cal}$. The heat 
Vol. I2

increment of the low acetic-acid mixture was the same whether it was given to supply $45^{\circ}$ or $900 \mathrm{Cal}$.

Synergistic effects. In previous experiments (Armstrong \& Blaxter, I957b) it was found that when the individual volatile fatty acids were given under similar conditions to fattening sheep, the heat increments were for acetic acid $67 \cdot 1$, for propionic acid 43.7 and for $n$-butyric acid $38 \cdot$ I Cal./ $100 \mathrm{Cal}$. These values can be used to predict the heat increments to be expected when the mixtures used in the present experiments were given. This calculation is given in Table 9. The heat increment expected on the basis of proportionality of response was $60.7 \mathrm{Cal} . / 100 \mathrm{Cal}$. for the high acetic-acid mixture, and a value of $68 \cdot 2 \mathrm{Cal}$. / $100 \mathrm{Cal}$. was obtained. The difference was $7 \cdot 5 \pm 3 \cdot 3 \mathrm{Cal}$./ $100 \mathrm{Cal}$. which is not significantly different from zero $(P>0.05)$. The calculated heat increment

Table 8. Calculation of heat increments of steam-volatile fatty-acid mixtures in four fattening sheep

\begin{tabular}{|c|c|c|c|c|c|c|c|}
\hline Treatment & $\begin{array}{l}\text { Approximate } \\
\text { calories } \\
\text { supplied } \\
(\mathrm{Cal} / 24 \mathrm{~h})\end{array}$ & Sheep & $\begin{array}{c}\text { Observed } \\
\text { when acids } \\
\text { given } \\
(\text { Cal. } / 24 \mathrm{~h})\end{array}$ & $\begin{array}{c}\text { Control } \\
\text { (Cal. } / 24 \text { h) }\end{array}$ & $\begin{array}{c}\text { Total } \\
\text { heat } \\
\text { increment } \\
\text { (Cal. } / 24 \mathrm{~h})\end{array}$ & $\begin{array}{c}\text { Actual } \\
\text { intake } \\
(\text { Cal. } / 24 \mathrm{~h})\end{array}$ & $\begin{array}{c}\text { Heat } \\
\text { increment } \\
\text { (Cal./roo Cal.) }\end{array}$ \\
\hline High acetic-acid mixture & $45^{\circ}$ & $\begin{array}{c}\mathrm{Pe} \\
\mathrm{Pa} \\
\mathrm{T} \\
\mathrm{S} \\
\text { Mean }\end{array}$ & $\begin{array}{l}213^{* *} \\
1996 \\
2076 \\
1953\end{array}$ & $\begin{array}{l}1823 \\
1700 \\
1759 \\
1680\end{array}$ & $\begin{array}{l}315 \\
296 \\
317 \\
273\end{array}$ & $\begin{array}{l}4^{61} \\
410 \\
4^{83} \\
408\end{array}$ & $\begin{array}{c}68 \cdot 3 \\
72 \cdot 2 \\
65 \cdot 6 \\
66 \cdot 9 \\
68 \cdot 2 \pm 1 \cdot 8\end{array}$ \\
\hline High acetic-acid mixture & 900 & $\begin{array}{l}\mathrm{Pe} \\
\mathrm{Pa} \\
\mathrm{T} \\
\mathrm{S}\end{array}$ & $\begin{array}{l}2094 \\
2108 \\
2237 \\
1965\end{array}$ & $\begin{array}{l}1823 \\
1700 \\
1759 \\
1680\end{array}$ & $\begin{array}{l}271 \\
408 \\
478 \\
285\end{array}$ & \multicolumn{2}{|c|}{ Not calculated $\uparrow$} \\
\hline Low acetic-acid mixture & $45^{\circ}$ & $\begin{array}{c}\mathrm{Pe} \\
\mathrm{Pa} \\
\mathrm{T} \\
\mathrm{S} \\
\text { Mean }\end{array}$ & $\begin{array}{l}2002 \\
1879 \\
1939 \\
1860\end{array}$ & $\begin{array}{l}1823 \\
1700 \\
1759 \\
1680\end{array}$ & $\begin{array}{l}179 \\
179 \\
180 \\
180\end{array}$ & $\begin{array}{l}401 \\
455 \\
464 \\
419\end{array}$ & $\begin{array}{c}44^{\circ} 6 \\
39^{\circ} 3 \\
38 \cdot 8 \\
43^{\circ} \circ \\
4 \mathrm{I} \cdot 4 \pm \mathrm{I} \cdot 8\end{array}$ \\
\hline Low acetic-acid mixture & 900 & $\begin{array}{c}\mathrm{Pe} \\
\mathrm{Pa} \\
\mathrm{T} \\
\mathrm{S} \\
\text { Mean }\end{array}$ & $\begin{array}{l}2126 \\
2121 \\
2164 t \\
2045\end{array}$ & $\begin{array}{l}1823 \\
1700 \\
1759 \\
1680\end{array}$ & $\begin{array}{l}303 \\
421 \\
405 \\
365\end{array}$ & $\begin{array}{l}804 \\
941 \\
904 \\
884\end{array}$ & $\begin{array}{c}37 \cdot 7 \\
44 \cdot 7 \\
44 \cdot 8 \\
4 \times \cdot 3 \\
42 \cdot I \pm r \cdot 8\end{array}$ \\
\hline
\end{tabular}

for the low acetic-acid mixture was lower than that found by experiment by $6 \cdot 0 \pm 3.5$ Cal./ $100 \mathrm{Cal}$., and this value too was not significantly different from zero. It appears, therefore, that the heat increments of the acid mixtures are those to be expected on the basis of direct proportionality of response to the individual acids. Further experimentation with acid mixtures should allow a more exact delineation of the region in which proportionality of response occurs and enable a more exact estimate to be made of the values for the individual acids.

Protein metabolism. Table so summarizes the results obtained relating to the $\mathrm{N}$ metabolism of the sheep. In agreement with the findings with the steam-volatile fatty 
acids given singly (Armstrong $\&$ Blaxter, $1957 b$ ), there was an increase in $\mathrm{N}$ retention when the mixtures were given, and a corresponding decline in the excretion of $\mathrm{N}$ in the urine. The effects were, however, greater than in the previous experiments. Table ro shows that the increase in heat production consequent upon metabolism of the fatty-acid mixtures measures their effect in promoting synthesis of both body protein and body fat in the ratio of $\mathrm{x}: 4$ or $\mathrm{I}: 5$. Much of this protein synthesis in these adult animals probably represents synthesis of the keratins of the fleece rather than of the proteins of the soft tissues (Marston, 1955).

Table 9. Heat increments of two mixtures of steam-volatile fatty acids for fattening sheep determined experimentally, and heat increments calculated from observations previously made (Armstrong $छ$ Blaxter, $1957 b$ ) on the heat increments of the individual acids

\begin{tabular}{|c|c|c|c|c|}
\hline Mixture & $\begin{array}{l}\text { Heat increment } \\
\text { determined } \\
\text { experimentally } \\
\text { (Cal./Ioo Cal.) }\end{array}$ & $\begin{array}{l}\text { Heat increment } \\
\text { calculated } \\
\text { from heat } \\
\text { increments of } \\
\text { individual acids } \\
\text { (Cal./ roo Cal.) }\end{array}$ & $\begin{array}{l}\text { Difference with its } \\
\text { standard error } \\
\text { (Cal./ Ioo Cal.) }\end{array}$ & $\begin{array}{c}\text { Odds against a } \\
\text { difference as large as } \\
\text { that observed } \\
\text { arising by chance }\end{array}$ \\
\hline High acetic acid & $68 \cdot 2 \pm r \cdot 8$ & $60 \cdot 7 \pm 2 \cdot 7$ & $+7 \cdot 5 \pm 3 \cdot 3$ & $13: 1$ \\
\hline Low acetic acid & $4 \mathrm{I} \cdot 9 \pm \mathrm{I} \cdot 2$ & $47 \cdot 9 \pm 3 \cdot 2$ & $-6.0 \pm 3.5$ & $7: 1$ \\
\hline
\end{tabular}

Table 10. Changes in $N$ metabolism of four sheep given two steam-volatile fatty-acid mixtures, and the contribution of protein retention to total energy retention

\begin{tabular}{|c|c|c|c|c|c|c|c|}
\hline \multirow[b]{2}{*}{ Treatment } & \multirow{2}{*}{$\begin{array}{l}\text { Approximate } \\
\text { calories } \\
\text { supplied } \\
\text { (Cal./24 h) }\end{array}$} & \multicolumn{2}{|c|}{ Urinary $\mathrm{N}$ excretion } & \multicolumn{2}{|c|}{$\mathrm{N}$ retention } & \multirow{2}{*}{$\begin{array}{c}\text { Calorie } \\
\text { equivalent } \\
\text { of increased } \\
\mathrm{N} \text { retention } \\
(\mathrm{Cal} / 24 \mathrm{~h})\end{array}$} & \multirow{2}{*}{$\begin{array}{c}\text { Total } \\
\text { increase } \\
\text { in energy } \\
\text { retention } \\
(\text { Cal. } / 24 \mathrm{~h})^{*}\end{array}$} \\
\hline & & $\begin{array}{c}\text { Actual } \\
(\mathrm{g} / 24 \mathrm{~h})\end{array}$ & $\begin{array}{l}\text { Decrease } \\
(\mathrm{g} / 24 \mathrm{~h})\end{array}$ & $\begin{array}{r}\text { Actual } \\
(\mathrm{g} / 24 \mathrm{~h})\end{array}$ & $\begin{array}{l}\text { Increase } \\
(\mathrm{g} / 24 \mathrm{~h})\end{array}$ & & \\
\hline Control & None & $13 \cdot 78$ & - & $+I \cdot 19$ & - & - & - \\
\hline $\begin{array}{l}\text { High acetic- } \\
\text { acid mixture }\end{array}$ & $\begin{array}{l}450 \\
900\end{array}$ & $\begin{array}{l}12 \cdot 91 \\
10 \cdot 93\end{array}$ & $\begin{array}{l}0.87 \\
2 \cdot 85\end{array}$ & $\begin{array}{l}+2.29 \\
+4.04\end{array}$ & $\begin{array}{l}I \cdot 10 \\
2 \cdot 85\end{array}$ & 39 & 140 \\
\hline $\begin{array}{l}\text { Low acetic- } \\
\text { acid mixture }\end{array}$ & $\begin{array}{l}45^{\circ} \\
900\end{array}$ & $\begin{array}{l}12 \cdot 6 \mathrm{r} \\
10 \cdot 86\end{array}$ & $\begin{array}{l}I \cdot 17 \\
2 \cdot 92\end{array}$ & $\begin{array}{l}+2.3 x \\
+4.08\end{array}$ & $\begin{array}{l}I \cdot 12 \\
2 \cdot 89\end{array}$ & $\begin{array}{r}39 \\
101\end{array}$ & $\begin{array}{l}255 \\
509\end{array}$ \\
\hline s.E. of differences & - & 一 & $\pm 0.4 I$ & - & $\pm 0 \cdot 45$ & - & - \\
\hline
\end{tabular}

* Calories given as steam-volatile fatty-acid mixtures less the mean increments of heat recorded in Table 8 .

\section{DISCUSSION}

In experiments of this type in which effects are measured as the differences in metabolism which occur when a dietary supplement is added to a basal ration, interpretation depends on the assumption that the metabolism of the basal ration remains unchanged. Any synergism that might take place between basal ration and supplement is necessarily attributed to a primary effect of the supplement.

In our experiments, the ways in which the supplements could affect the utilization of the basal ration all relate to their effect on the microbial populations of the rumen and the nature and amounts of the products of digestion absorbed. In the experiments with the high acetic-acid mixture given to supply $900 \mathrm{Cal}$. there was evidence that the 
population had been disturbed. Thus $\mathrm{CH}_{4}$ production fell and the loss of energy in the faeces increased. Yet the accompanying changes in the $\mathrm{pH}$ and the content of total and individual steam-volatile fatty acids in the rumen liquor were not large, nor was there any change in blood composition to indicate altered metabolic activity of the rumen flora. Clearly, the occurrence of only small changes in the $\mathrm{pH}$ and steamvolatile fatty-acid content of rumen liquor cannot be taken as evidence that the microbiological processes in the rumen have not been altered. The absence of gross abnormality of composition in the rumen liquor or blood when the other three mixtures were given thus provides no real justification for the assumption that the mixtures had no effect on the rumen flora. In these three experiments, however, there was no change in the faecal excretion of energy and, although $\mathrm{CH}_{4}$ production fell, the depressions were small. Together these two observations suggest that the fermentation of the basal ration was not affected to any appreciable extent. Nevertheless, they do not provide a complete justification for this assumption. Our present results and those obtained previously (Armstrong \& Blaxter, $1957 b$ ) may not have, therefore, the accuracy their standard errors imply. The possibility of synergism between basal ration and supplement is still present, though its likelihood is small. This must be borne in mind when considering the results.

The mean results show that two different mixtures of steam-volatile fatty acids, given to sheep which were retaining energy in their bodies, were used to effect a net synthesis of fat and resulted in an economy in $\mathrm{N}$ metabolism. The ratio of fat energy to protein energy retained was 4 or $5: \mathrm{I}$. The energy cost of synthesizing peptide bonds from amino-acids may be considerable (Borsook \& Huffman, 1938) but information on its efficiency when oxidation of steam-volatile fatty acids provides the source of energy for the synthesis is not available. There is, in fact, difference of opinion between investigators on whether the efficiency of utilization of energy in growth, which entails considerable protein deposition, is greater than that in fattening (Breirem, 1939; Wiegner \& Grünigen, I934). The major product of the synthesis in the present experiments, however, was fat. For this synthesis the mixtures were used with widely differing efficiencies which were for practical purposes the sum of the effects of the acids when given singly under similar conditions (Armstrong \& Blaxter, $1957 b$ ).

The utilization of the steam-volatile fatty acids above the maintenance datum thus differs very markedly from their metabolism below maintenance. Not only are heat increments higher above maintenance than below, but above maintenance the composition of the mixture of acids has a marked effect on the magnitude of the increment of heat, whereas below maintenance mixtures of widely differing composition are used with equal efficiency (Armstrong et al. 1957).

If the major metabolites arising from bacterial dissimilation of carbohydrate which reach the tissues of the ruminant are the steam-volatile fatty acids (see Phillipson \& Cuthbertson, 1956), then foods must have different nutritive values in terms of energy when they are used above and below the maintenance datum. Above maintenance a unit of food will be less efficiently used than below maintenance. This has long been realized. Results from several laboratories show that with normal rations the net availability of the metabolizable energy of food for maintenance is about $85 \%$ and 
that for fattening about $55 \%$ (see Blaxter, I950-1). What is implied by the present results is that besides there being a general reduction of efficiency above maintenance, the reduction might be greater with some foods than with others.

There is much information to support this contention. In Table I I, the results of experiments by Ritzman \& Benedict (1938), Armsby (1917) and Kellner (1900) have been compared. Ritzman \& Benedict in a long series of experiments found that their cows required slightly more metabolizable energy to maintain them when the food was hay $(32 \%$ crude fibre) than when it was maize (3\% crude fibre). Kellner ( 1900 ) in experiments with hays containing $30-32 \%$ crude fibre given to fattening oxen above maintenance found that the net availability of the metabolizable energy was $35 \%$ (see Breirem, I954; Werner \& Franke, I953). Armsby (I9I7), in experiments with maize given above maintenance, found the net availability of its metabolizable energy to be

Table I I. Results of experiments of Ritzman $\mathcal{F}^{\circ}$ Benedict (1938), of Armsby (1917) and of Kellner (1900) restated to show that foods differ in their relative nutritive value according to whether they are used to provide for maintenance or for production of fat

\begin{tabular}{|c|c|c|c|}
\hline Food & $\begin{array}{l}\text { Crude fibre } \\
\text { of food } \\
(\%)\end{array}$ & $\begin{array}{l}\text { Metabolizable } \\
\text { energy (Cal.) } \\
\text { for maintenance* } \\
\text { (7000 net Cal.) }\end{array}$ & $\begin{array}{l}\text { Metabolizable } \\
\text { energy (Cal.) } \\
\text { required for } \\
\text { I kg fat gained } \\
\text { (9300 Cal. gain) }\end{array}$ \\
\hline Hay & $3 I \cdot 8$ & $\mathrm{I} 2, \mathrm{I} 73$ & $26,600 \dagger$ \\
\hline Maize & $3 \cdot 3$ & 10,370 & $14,600 t$ \\
\hline Conclusions & - & $\begin{array}{l}\text { Metabolizable energy of } \\
\text { maize utilized I } 7 \% \\
\text { better than that of hay }\end{array}$ & $\begin{array}{l}\text { Metabolizable energy of } \\
\text { maize utilized } 82 \% \\
\text { more efficiently than } \\
\text { that of hay }\end{array}$ \\
\hline
\end{tabular}

* Mean results of Ritzman \& Benedict (1938) for twenty-nine experiments with hay, net availability $57.7 \%$ and four experiments with maize meal, net availability $67.5 \%$. The maintenance requirement was taken to be 7000 net Cal. (Blaxter, 1950-I).

$\dagger$ Results of Armsby ( 1917 ), net availability of metabolizable energy of maize $63.5 \%$ (heat increment $36.5 \%$ ).

$\ddagger$ Results for Kellner's ( 1900 ) ox H and ox J given hay, net availability of metabolizable energy $35 \%$ (heat increment $65 \%$ ).

$63.5 \%$. If I $\mathrm{kg}$ of body fat $(9300 \mathrm{Cal} / \mathrm{kg})$ were formed then the amount of metabolizable energy required as hay would be $9300 / 0 \cdot 35=26,600 \mathrm{Cal}$. and as maize $9300 / 0 \cdot 635=14,600 \mathrm{Cal}$., which are the figures given in the table. The results thus show that whereas for maintenance the metabolizable energy of maize is about $17 \%$ better utilized than that of hay, for fat deposition the metabolizable energy of maize is utilized $82 \%$ better than that of hay. It also follows that the high heat increment of hays determined by Kellner in fattening experiments cannot be entirely ascribed to the physical work that the fattening animal performs in eating them. Otherwise, the difference in the amount of metabolizable energy needed to maintain cows with hay would have been considerably higher than the 11 $8 \%$ of the amount necessary to maintain them when maize was given.

These results, admittedly compiled from three different sources, show that the relative nutritive value of two foods can vary according to whether they are used to promote synthesis or are used to supply the energy needs of maintenance. The studies 
with the steam-volatile fatty acids suggest that these differences arise because the individual steam-volatile fatty acids produce different increments of heat above maintenance, whereas below maintenance they are all used equally well. If high efficiency of use for maintenance is contingent upon oxidation of the acids then it would be expected that, in working animals, foods would be used with a similar efficiency. This contention, however, has not been subject to experimental proof.

Furthermore, variation in the proportions of the energy absorbed from different diets in the form of hexose, and as the individual acids, no doubt occurs.

\section{SUMMARY}

I. Twenty-eight experiments were made with four sheep given a maintenance ration of dried grass. In these experiments dilute saline or one of two mixtures of steam-volatile fatty acids was administered. The acid mixtures contained acetic, propionic and $n$-butyric acids in the molar proportions $75: 15: 10$ and 25:45:30 and each was given to supply $45^{\circ}$ Cal. or 900 Cal. daily.

2. The mixtures had very small effects on the $\mathrm{pH}$ and steam-volatile fatty-acid content of rumen liquor, and no effect on the $\mathrm{CO}_{2}$-combining capacity of the plasma, the sugar, steam-volatile fatty-acid and ketone contents of the blood.

3. A depression of $\mathrm{CH}_{4}$ production occurred when $900 \mathrm{Cal}$. of either mixture were given, the depression being very considerable with the mixture containing the larger amount of acetic acid. The faecal loss of energy also increased in the experiments with $900 \mathrm{Cal}$. of this mixture.

4. The increments of heat were $68 \cdot 2 \pm \mathrm{r} \cdot 8 \mathrm{Cal} / \mathrm{I} 00 \mathrm{Cal}$. acid given for the smaller quantity of mixture containing $75 \%$ acetic acid and $4 \mathrm{r} \cdot 9 \pm \mathrm{r} \cdot 2 \mathrm{Cal} / \mathrm{roO}$ Cal. acid given for both mixtures containing the lower molar proportion of acetic acid. There were no significant synergistic effects as judged by the results of previous experiments (Armstrong \& Blaxter, $1957 b$ ) with individual acids.

5. The results are discussed, and it is pointed out that the energy of the steamvolatile fatty acids appears to be more efficiently utilized oxidatively in meeting maintenance needs than it is for lipogenesis. Differences in the relative nutritive value of concentrates and roughages for maintenance and for lipogenesis can possibly be explained in this way.

We are grateful to $\mathrm{Mr} \mathrm{D}$. Paterson and Mr D. MacSporran for their help with the respiration apparatus and to the Misses E. Bryce, M. Jack, J. Muir and E. Rennie for analytical work.

\section{REFERENCES}

Armsby, H. P. (1917). The Nutrition of Farm Animals. New York: The Macmillan Co.

Armstrong, D. G. \& Blaxter, K. L. (I957a). Brit. F. Nutr. Ir, 247.

Armstrong, D. G. \& Blaxter, K. L. (1957b). Brit. F. Nutr. II, 4I3.

Armstrong, D. G., Blaxter, K. L. \& Graham, N. McC. (1957). Brit. F. Nutr. II, 392.

Blaxter, K. L. (1950-1). Nutr. Abstr. Rev. 20, I.

Blaxter, K. L. \& Graham, N. McC. (1955). F. agric. Sci. 46, 292.

Blaxter, K. L. \& Graham, N. McC. (1956). F. agric. Sci. 47, 207. 
Borsook, H. \& Huffman, H. M. (1938). In The Chemistry of the Amino Acids and Proteins, p. 822. [C. L. A. Schmidt, editor.] Springfield, I1l.: Charles C. Thomas.

Breirem, K. (1939). Tierernährung, r1, 487.

Breirem, K. (1954). In Festschrift anlässlich des 100 jährigen Bestehens der Landwirtschaftlichen Versuchsstation Leipzig-Möckern. Vol. 2. 100 Fahre Möckern. Die Bewertung des Futterstoffe und andere Probleme der Tierernährung, p. 91. [K. Nehring, editor.] Berlin: Deutscher Bauernverlag.

James, A. T. \& Martin, A. J. P. (1952). Biochem. F. 50, 679.

Kellner, O. (I 9oo). Landw. VersSta. 53, I.

Marston, H. R. (1955). In Progress in the Physiology of Farm Animals, Vol. 2, p. 543. [J. Hammond, editor.] London: Butterworths Scientific Publications.

Phillipson, A. T. \& Cuthbertson, D. P. (1956). Int. Congr. Anim. Husb. vir. Madrid, 6, 7.

Ritzman, E. G. \& Benedict, F. G. (1938). Publ. Carneg. Instn, no. 494.

Werner, A. \& Franke, E. R. (1953). In Festschrift anlässlich des 100 jährigen Bestehens der Landwirtschaftlichen Versuchsstation Leipzig-Möckern. Vol. 1. Untersuchungen über den Stärkewert verschiedener Futtermittel, p. 335. [K. Nehring \& A. Werner, editors.] Berlin: Deutscher Bauernverlag.

Wiegner, G. \& Grünigen, F. (1934). Arb. dtsch. Ges, Zücht. 63, I.

\title{
The amino-acid composition of potato protein and of cooked potato
}

\author{
By B. P. HUGHES* \\ Medical Research Council Department of Experimental Medicine, \\ University of Cambridge \\ (Received 7 September 1957)
}

The potato's nitrogenous constituents have a nutritive value as high as do those of whole wheat (Chick \& Cutting, I943). This has long seemed surprising, for the proportion of protein nitrogen in the potato may be as low as $37 \%$ and appears not to exceed about $60 \%$ (Neuberger \& Sanger, 1942; Mulder \& Bakema, 1956) of the total nitrogen. The non-protein nitrogen, which consists largely of asparagine and glutamine together with other nitrogenous bases (Neuberger \& Sanger, 1942), is of low nutritive value with no growth-promoting properties on its own (Chick \& Cutting, I943; Chick \& Slack, I949), but nevertheless appears to have a supplementary action when mixed with wheat gluten (Chick \& Slack, unpublished, reported by Chick, I950).

The existing amino-acid analyses of the heat-coagulable protein that forms the bulk of the potato protein (Neuberger \& Sanger, 1942; Mulder \& Bakema, 1956), of the non-protein nitrogen and of the whole raw potato have so far provided only in part an explanation of these facts; moreover, there are considerable discrepancies between the results of different authors.

For these reasons it seemed worth while to repeat and extend some of the analyses by the method of ion-exchange chromatography of Moore \& Stein (I951). The isolated, crude potato protein has been analysed and also the whole potato after being

* Present address: Institute of Neurology, The National Hospital, Queen Square, London, W.C. I. 